\title{
Media Sosial Dan Praktik-Praktik Voyeurism
}

\author{
Social Media Voyeurism
}

\author{
Nadia Sofiyanti', Puji Rianto ${ }^{2}$ \\ Program Studi Ilmu Komunikasi, Universitas Islam Indonesia, Sleman \\ Yogyakarta, Indonesia
}

\section{Author's email:}

${ }^{1}$ Email:

nadia.sofiyanti@students.uii.ac.id

${ }^{2}$ Email:

puji.rianto@uii.ac.id

\begin{abstract}
:
Voyeurism is generally understood as deviant sexual behavior. However, it actually covers a wide dimension. The presence of social media makes voyeurism practices more open because of the participatory nature of social media. This study aims to determine the voyeurism in some Yogyakarta student informants related to the motives for doing voyeurism. This study used qualitative research methods. Data collection techniques used in-depth interviews and observation participation on social media. The results revealed several peeping habits, motives and satisfaction when doing voyeurism. Several features on Instagram make it easier for perpetrators to work. Motives are also very diverse. However, the most common is getting sexual gratification from the practice of snooping. In particular, for male actors.
\end{abstract}

Keywords: Voyeurism, Social Media, Instagram, motive and gratifications

\begin{abstract}
Abstrak:
Voyeurism umumnya dipahami sebagai perilaku seksual menyimpang. Namun, sebenarnya ia mencakup dimensi yang luas. Kehadiran media sosial membuat praktik-praktik voyeurism semakin terbuka karenanya sifat partisipatif media sosial. Penelitian ini bertujuan mengetahui voyeurism di beberapa informan mahasiswa Yogyakarta terkait motif-motif melakukan voyeurism. Penelitian ini menggunakan metode penelitian kualitatif. Teknik pengumpulan data menggunakan wawancara mendalam dan partisipasi observasi di media sosial. Hasil penelitian mengungkapkan beberapa kebiasaan mengintip, motif dan kepuasan saat melakukan voyeurism. Beberapa fitur di Instagram mempermudah kerja pelaku. Motif juga sangat beragam. Namun, yang paling umum adalah mendapatkan kepuasan seksual dari praktik mengintip tersebut. Khususnya, bagi para pelaku laki-laki.
\end{abstract}

Kata kunci: voyeurism, Media Sosial, Instagram, motif dan kepuasan 


\section{PENDAHULUAN}

Voyeurism dapat dikatakan sebagai perilaku seseorang yang memiliki minat berlebih untuk melihat atau mengobservasi orang lain (Ningtyas, 2016). Kegiatan voyeurism atau dapat dikatakan dengan "mengintip" adalah salah satu kegiatan yang secara sadar sering dilakukan oleh individuindividu dengan beberapa motif. Kegiatan voyeurism lebih mengarah pada konsumsi yang berlebihan pada suatu atau banyak gambar dan informasi tentang orang lain sehingga akan tampak nyata serta akan menyalah-artikan identitas seseorang melalui media dan internet (Calvert, 2009). Voyeurism dapat terjadi karena dilatarbelakangi oleh faktor internal. Faktor internal merupakan faktor pendorong seseorang untuk melakukan voyeurism. Faktor pendorong dapat muncul sebagai insting atau perasaan spontan. Di atas semua itu dan tanpa disadari, voyeurism atau perilaku mengintip itulah yang menarik atau menuntun kita untuk menikmati citra hidup orang lain yang sengaja dipertontonkan oleh media dan lebih besar terjadi di televisi dan internet (Calvert, 2009). Keberadaan media telah menciptakan apa yang kemudian dimaksud sebagai voyeurisme termediasi (mediated voyeurism).

Kehadiran media digital semakin membuka ruang bagi praktik-praktik mengintip. Dalam hal ini, media sosial merupakan medium yang memfasilitasi para stalker (sebutan untuk orang yang melakukan kegiatan voyeurism) untuk melaksanakan aktivitasnya. Hanya dengan membuka browser dan mengetikkan kata kunci, semuanya dapat tersaji. Fitur mention akan memunculkan username seseorang dan dengan satu kali klik dapat melihat akun dengan username tersebut.

Instagram menjadi salah satu media sosial yang banyak digunakan untuk mengintip. Ini karena adanya beberapa fasilitas, di antaranya fitur instastory atau snapgram. Melalui fasilitas ini, pemilik dapat menginformasikan bahwa ia sedang berada di suatu tempat dan dilengkapi dengan tautan lokasi tempat beserta foto dan video yang tersimpan selama 24 jam dari waktu posting, juga dapat ditambah dengan link suatu website (banyak digunakan untuk mempromosikan tentang suatu web atau lainnya). Dalam fitur snapgram, juga tertera pada fitur explore sehingga semua orang dapat melihat aktivitas yang kita post pada story atau snapgram. Hal diatas cukup memfasilitasi para pengintip atau stalker. Adapun fitur hashtag (\#) yang disertai kata tertentu membuat pengguna lebih mudah dalam menemukan apa yang dicari.

Mengintip tidaklah asing. Ini karena sudah menjadi kebiasaan lama bagi beberapa individu. Selain itu, juga didukung dengan sikap orang lain yang sengaja mengunggah kegiatan pribadi. Ini membuat pengintip memungkinkan melakukan voyeurism secara terus-menerus (Ningtyas, 2016). Ibaratnya, seperti ada yang kurang apabila belum mengetahui bagian terkecil dari kehidupan orang lain.

Beberapa penelitian telah dilakukan mengenai praktik-praktik mengintip ini. Penelitian Su (2012) di media sosial Facebook menunjukkan bahwa orang-orang saling melakukan add as friend dengan orang lain juga akan berpotensi untuk melakukan voyeurisme. Ada keterkaitan antara kecenderungan voyeuristik dan Facebook disertai dengan kebutuhan sosial agar dapat dijadikan sebagai perbandingan dalam kehidupan juga dari segi identitas sosial.

Matti Mantymaki dan Islam memaparkan bahwa pengguna media sosial memiliki dua peran saat memproduksi dan membagikan kontennya yaitu sebagai pembuat dan juga untuk dikonsumsi orang lain. Peneliti menuliskan bahwa teori uses and gratification sangat berpengaruh pada voyeurism dan exhibitionism. Penelitian tersebut menunjukkan bahwa mengkonsumsi konten pada media sosial akan menyebabkan munculnya voyeurisme dan ekshibisionisme. Penelitian ini diuji pada 289 pengguna aktif Facebook. Riset lainnya yang dilakukan Chandra (2019) 
menunjukkan bahwa rasa ingin tahu seorang manusia adalah sifat alami dan juga termasuk dari bagian kehidupan. Dari situlah, para individu berusaha untuk memasuki kehidupan bahkan dengan sikap agresif seseorang dengan cara mengintip melalui media sosial. Terutama karena mereka merasa hal itu aman untuk dilakukan. Voyeurism merupakan hasrat pada diri seseorang yang memiliki kepuasaan tersendiri terhadap hal-hal yang berbau seksual seperti melihat orang lain atau hanya sekadar melihat bagian tubuh tertentu dari orang lain (Chandra, 2019).

Penelitian yang dilakukan Rye \& Meaney (2007) pada mahasiswa di sebuah universitas dengan menggunakan berbagai tipe tes, seperti melihat orang yang sedang membuka pakaian dan melihat aktivitas sexual. Dari eksperimen tersebut, ditemukan bahwa lebih banyak peserta yang lebih suka melihat aktivitas dan peserta pria lebih banyak daripada wanita. Dengan demikian, sangat sesuai untuk membentuk dan mengarahkan perspektif pada hal-hal yang berkaitan dengan voyeurism. Meskipun begitu, riset Yalom (1960) justru menyimpulkan bahwa voyeurism merupakan suatu perilaku seseorang, yang mana kemunculannya tidak pasti. Penulis juga mengatakan bahwa banyak hal-hal yang berkaitan dengan voyeurism tidak dapat dipastikan, selain perilaku. Praktik voyeurism dikatakan lebih ringan dalam kasus perempuan telanjang yang menunggang kuda demi keringanan pajak.

Dalam artikel Green (2017) yang didasarkan pada sebuah insiden di sebuah desa di Inggris di mana seorang istri rela bertelanjang dan menunggang kuda sepanjang jalan demi pencabutan pajak oleh suaminya untuk meringankan beban rakyatnya. Dalam kasus tersebut, voyeurism dinilai lebih ringan jika dibandingkan dengan kasus pelanggaran berbau seksual lainnya. Hal ini membuat munculnya pertanyaan dari masyarakat bagaimana tindakan hukum yang berlaku untuk mengatasi voyeurism. Pelaku voyeurism melakukan pelanggaran dengan memasukkan korban ke dalam wilayahnya. Hal ini sangat tidak sesuai dengan pelanggaran seksual lainnya. Voyeurism cenderung tidak jelas. Penulis mengatakan bahwa hal ini akan semakin buruk seiring dengan kemunculan teknologi yang dinilai akan menentang hal-hal yang bersifat pribadi. Penulis juga menyatakan bahwa voyeurisme dan ekshibisionisme merupakan penyakit mental yang ditandai dengan praktik seksual yang menyimpang.

Penelitian ini dilakukan dengan mengambil subjek mahasiswa yang ada di kota Yogyakarta. Mahasiswa dinilai sebagai subjek yang sesuai karena pada 18 hingga awal 20 tahun merupakan usia produktif pada masyarakat yang paling melek teknologi dan mengerti apa yang akan dicari di media sosial Instagram terlepas dari isi konten Instagram tersebut. Tujuan penelitian ini terutama untuk mengungkap motif-motif individu (dalam hal ini mahasiswa yang menjadi informan) dalam melakukan voyeurism.

\section{KERANGKA TEORI}

Voyeurism atau mengintip merupakan budaya yang muncul di kalangan masyarakat yang memiliki kaitan dengan konsumsi visual atau menonton. Adanya voyeurism terbentuk dari keinginan dalam diri untuk mengetahui kehidupan orang lain. Adanya rasa ingin tahu yang mengarah pada hal-hal yang melanggar hak privasi orang lain. Hingga saat ini, voyeurism menjadi "budaya" yang sulit untuk dihilangkan dan sudah menjadi kebiasaan pada hampir sebagian masyarakat (Aprianti, 2014). Seperti dituliskan Clay Calvert dalam Voyeur Nation, voyeurism atau budaya mengintip akan tumbuh dengan mudahnya saat seseorang melihat gambar yang mengungkapkan tentang keaslian pada kehidupan orang lain yang menurut masyarakat luas hal tersebut tidak dijaga oleh pemilik gambar. Ini sangat bertolak belakang dengan konsep privasi kehidupan. Adanya teknologi semakin mempermudah pelaku voyeurisme dalam melakukan kegiatan mengintip. Keberadaan media sosial juga membuat aksinya lebih aman. 
Media sosial merupakan platform yang berbasis media serta terfokus pada eksistensi pengguna media sosial yang memfasilitasi saat melakukan aktifitas dan juga saat berkolaborasi. Oleh karena itu, media sosial dapat dikatakan sebagai fasilitator dalam hal bidang online yang dapat memberikan kekuatan hubungan antar pengguna sekaligus juga sebuah ikatan sosial (Nasrullah, 2016).

Dalam menggunakan media sosial, para pengguna memiliki tujuan antara lain sebagai interaksi sosial (social interaction), berhubungan dengan fungsi media yang dapat digunakan untuk berkomunikasi, baik individu satu dengan yang lain tetap terhubung meski berjauhan (Innova, 2016). Media juga dapat sebagai hiburan (entertainment) karena dinilai dapat menyajikan konten-konten yang dapat membuat seseorang merasa terhibur, motif selanjutnya bahwa media dapat memberikan kenyamanan (convenience utility) tersendiri bagi para penggunanya (Innova, 2016). Motif keempat adalah menggunakan media untuk menghabiskan waktu (pass time), media sebagai relaksasi (relaxation). Motif yang terakhir seseorang menggunakan media atau Instagram adalah kegunaannya sebagai alat komunikasi (communicatory utility). Merupakan motif utama bahwa media atau Instagram adalah sebuah fasilitas untuk berkomunikasi.

Terdapat bermacam motif yang mendasari para pelaku untuk melakukan voyeurisme antara lain mengisi waktu senggang hingga untuk memenuhi hasrat seksual para pelaku. Motif yang berkaitan dengan kehidupan sosial antara lain social identity. Pelaku voyeurism akan menelusuri konten yang berada di media sosial untuk seterusnya ditiru dan juga setiap orang yang berada dalam satu kelompok sehingga akan melekat sebagai identitasnya. Hal ini akan menimbulkan pemikiran atau persepsi tersendiri terhadap target voyeurism, dapat berupa persepsi negatif tentang target. Dalam teori Uses and gratification, pelaku voyeurisme akan mencari konten sesuai yang diinginkan, dan berharap hal itu dapat memberikan kepuasan tersendiri (Ningtyas, 2016). Hal ini berbeda dengan hanya menonton. Voyeurism didasari oleh motif-motif tertentu seperti cuci mata atau bahkan sekadar kepuasan tersendiri yang didapat ketika melihat orang lain dengan kriteria tertentu yang menurut pelaku tindak voyeurism menarik. Hal itu akan terus dilakukan berulang karena dinilai memberikan mereka kepuasan.

\section{METODE}

Penelitian ini menggunakan pendekatan kualitatif. Menurut (Moleong, 2011: 6), penelitian kualitatif merupakan sebuah penelitian yang ditujukan untuk dapat mengerti hal-hal yang terjadi pada saat itu serta memiliki hubungan langsung dengan subjek. Observasi merupakan metode awal yang digunakan melalui media sosial dengan memanfaatkan fitur Instagram seperti melakukan dengan memanfaatkan algoritma Instagram setelah mem-follow akun Instagram calon informan dan menetapkan beberapa kriteria seperti menyukai, selalu melihat postingan target, berkomentar hingga mengirimkan pesan langsung kepada targetnya. Untuk observasi kategori korban, ditetapkan kriteria seperti paras yang cantik, tubuh yang proporsional, juga pakaian yang sedikit terbuka atau menegaskan lekuk tubuh.

Subjek penelitian ini adalah mahasiswa di Kota Yogyakarta. Mahasiswa dipilih sebagai subjek karena memiliki literasi yang lebih baik. Wawancara mendalam juga dilakukan terhadap mahasiswa yang dipilih secara purposive. Kriteria informan adalah perempuan atau lakilaki yang memiliki intensitas tinggi dalam menggunakan media sosial Instagram serta dalam search history Instagram sehingga mereka berpotensi menggunakan beberapa fitur Instagram. Data sekunder dapat diperoleh dari artikel ilmiah, buku dan juga internet. Seluruh informan merupakan mahasiswa aktif yang menempuh studi di Yogyakarta. Aktif di media sosial Instagram(menyukai konten tertentu, mengikuti beberapa akun, sering berkomentar 
pada konten orang lain dengan kisaran usia 1825 tahun.

Analisis data adalah prosedur dalam menggali dan menata semua data yang telah didapat dari responden atau dari sumber ilmiah yang selanjutnya akan disusun kedalam bagianbagiannya lalu akan dijelaskan dan dipilih yang mana sekiranya dibutuhkan dalam penelitian agar mendapatkan hasil yang akurat dan ditarik kesimpulan dari seluruh aspek penelitian yang dilakukan (Sugiyono, 2013). Beberapa cara untuk menganalisis data menurut Sugiyono (2009), yaitu 1) Reduksi data; 2) Penyajian data; 3) Kesimpulan.

\section{HASIL DAN PEMBAHASAN}

Penelitian ini menemukan beberapa kategori yang berkaitan dengan hasil wawancara seperti pelaku, sarana yang digunakan, motif dan kepuasan. Untuk memperkaya penelitian, konteks juga diperhatikan. Ini untuk mengetahui kondisi seperti apa yang mendukung mereka melakukan voyeurism.

\section{Para Pengintip dan Metode}

Followers dan Orang Asing

Seluruh pernyataan yang dilontarkan informan menyebutkan bahwa mereka pernah melakukan voyeurisme kepada teman atau followers mereka sendiri, dan tidak semua followers adalah orang yang mereka kenal. Para korban juga selalu berpikir orang yang tidak mereka kenal, dan followers-nya adalah orang yang pasti melakukan voyeurism terhadap dirinya. Informan menyatakan, "Yaa dari followers dan following. Kadang ada yang saya kenal, kadang ada orang yang tidak saya kenal sama sekali" (informan 2, wawancara, 2020). Informan 2 lebih sering mendapati followersnya atau teman yang melakukan voyeurism terhadap dirinya dibandingkan orang asing. Ini berbeda dengan informan 3 .

"Kalau untuk siapa saja yang ngamatin aku itu banyak bener-bener serandom itu jadi dari teman dekat pun ada banget, yang sudah berteman bertahuntahun juga ada, yang teman biasa ngga deket juga ada. orang random ada bahkan stranger yang benar-benar baru pertama kali tau namanya itu juga ada, jadi aku tidak pernah dengar namanya sebelumnya. Serandom itu sih orangorang" (Informan 3, wawancara, 2020).

Informan 3 menilai bahwa lebih banyak orang asing yang melakukan voyeurism padanya, jika dibandingkan dengan temannya. "Godain pernah, mengajak berkenalan pernah. Tapi kalo godain gitu teman-teman yang sudah kenal dekat aja sih" (Informan 7, wawancara, 2020). "Kalau saya tidak sih. Lebih ke temanteman dekat sendiri yang suka nge-roasting. Misal aku pakai baju yang agak menonjol gitu ya dadanya lalu temanku kadang suka bilang balon atau apa. Kesel tapi teman sendiri dan akrab sih, memang kadang tidak tahu tempat saja hehehehe." (Informan 1, wawancara, 2020). Menurut informan 1, dirinya dapat menoleransi perilaku voyeurism yang dilakukan oleh temannya. Perasaan kesal akibat voyeurism yang dilakukan temannya diabaikannya untuk menjaga perasaan temannya tersebut.

\section{Spamming pada Direct message}

Media sosial Instagram yang dilengkapi dengan fitur DM atau Direct message (pesan langsung) dengan tujuan untuk berkomunikasi secara lebih privat. Apabila pelaku voyeurism juga mengomentari postingan seseorang di Instastory, pesan tersebut akan masuk ke pesan langsung. Kemungkinan hal itu dinilai akan lebih efektif oleh pelaku karena ditujukan langsung pada korbannya.

"Contohnya seperti dia tidak follow aku, dia pakai fake account, sudah saya block. Dia mengirimkan foto alat kelaminnya. Itu sudah diblokir sekali lalu sudah beberapa hari kemudian atau beberapa minggu kemudian mengirim 
foto lagi. Tapi saya tidak tahu itu orang yang sama atau tidak tapi juga samasama pakai fake account. Akhirnya saya blokir lagi. Nah untungnya pas aku blokir yang kedua kali itu sudah tidak pernah ada yang dm lagi" (Informan 4, wawancara, 2020).

Menurut informan 4, tindak voyeurism yang terjadi pada dirinya tetap terulang meskipun sudah melakukan penolakan seperti memblokir akun pelaku hingga meminta bantuan kepada followers-nya untuk memblokir. Melakukan pemblokiran dalam jumlah banyak membuat pelaku berhenti untuk mengintip.

"Iya aku merasa diamati orang-orang di Instagram. Misal ketika saya membuat snapgram, ketika saya memposting foto di feeds, itu ada orang yang $\mathrm{mmm}$ misalnya mengomentari konten di SG saya atau di foto-foto di IG. Kadang juga ada orang yang sama, satu orang yang sama sering setiap saya membuat SG dia selalu ngomentari SG saya, entah itu ngomentari menggunakan kata-kata atau entah itu pakai emot aja. Nah kadang juga ada beberapa orang yang setiap saya membuat $S G$ atau foto di Ig itu orang yang asing gitu lo, orang yang tidak saya kenal bukan ini saya $\mathrm{mmm}$ bukan followingnya saya gitu" (Informan 2, wawancara, 2020).

Para informan menyebutkan bahwa mereka lebih banyak mendapat tindak voyeurism dari pelaku berupa direct message bahkan mengirimkan foto yang tidak pantas.

\section{Motif-Motif dan Kepuasan}

Dari Memenuhi Hasrat Seksual hingga Fashion

Ada banyak motif yang mendasari perilaku mengintip. Motif-motif itu terutama karena ingin mendapatkan suatu gratifikasi atau kepuasan tertentu. Media sosial Instagram merupakan media sosial dengan fungsi utama untuk berbagi momen melalui foto maupun video, tetapi di sisi lain banyak yang menyalahgunakan media sosial Instagram. Salah satu bentuk penyalahgunaannya adalah untuk mengintip. Pelaku voyeurism dapat melakukan hal tersebut pada siapapun bahkan teman atau followers hingga orang yang belum dikenalnya sama sekali. Ini dapat dilihat dari kutipan informan yang mengaku sebagai pelaku tindak voyeurism

"Ya, suka aja buat cuci mata gitu lo. Paham tidak sih seperti oh ternyata di luar sana tu banyak orang-orang cakep gitu dan fashionable. Sama buat ini sih misalnya aku ngamatin dari fashion mungkin buat referensi fashion juga buat itu misalnya ngamatin Instagram orang lain" (Informan 5, wawancara, 2020).

Informan pertama sebagai pelaku mengatakan hanya sebatas mengagumi fisik orang lain dan selanjutnya untuk dijadikan sebagai referensi dalam hal fashion.

"Ya saya suka mengamati kebiasaan orang lain dan postingan orang lain di Instagram, karena yang saya amati itu yang saya follow kebanyakan adalah teman saya, teman dekat atau sebut saja kolega saya. Saya biasanya mengamati perkembangan mereka yaa mereka lagi ngapain atau kegiatan mereka atau sedang jalan-jalan dimana, karena itu nanti akan bisa menjadi obrolan ketika kita ketemu nanti gitu" (Informan 6, wawancara, 2020).

Dari kutipan informan 6, diketahui bahwa dia sering mengamati kegiatan followers atau temannya yang menurutnya sangat berguna sebagai topik obrolan saat mereka nanti bertemu. Mengamati orang lain selain teman pernah dilakukannya seperti pada kutipan, "Kalau dulu banget tu pernah, dan itupun orang yang saya kenal, tapi semenjak ikut kelas mata 
kuliah di kampus udah engga sih. Ini karena akupun menyadari kalau wanita sering sekali menjadi objektifikasi lelaki, dan itu masalah serius menurut saya, pelecehan seksual" (Informan 6, wawancara, 2020).

Pemenuhan hasrat seksualitas juga tidak luput dari motif voyeurism, "Pernah, sering kayaknya. Stalking yang berbau seksual kan. Wajar soalnya cowo" (Informan 7, 2020). Dari kutipan ini, dapat diketahui bahwa voyeurism atau kegiatan mengintip orang lain khususnya di media sosial Instagram yang dilakukan informan 7 merupakan hal yang wajar karena dirinya adalah laki-laki dan juga sering dilakukannya. Oleh karena laki-laki, adalah wajar jika mengintip demi kepuasan seksual.

Melakukan tindak voyeurism mungkin didasari tujuan yang berbeda-beda setiap orangnya, seperti untuk mendapat kepuasan tersendiri maka dia melakukan voyeurism. Hal ini berkaitan dengan pendekatan Uses and Gratifications, yang mana para pelaku voyeurism menggunakan Instagram sebagai sumber yang paling tepat untuk memenuhi kepuasan mereka. Para pelaku dapat menggunakan fitur yang disediakan Instagram untuk mencari hal yang dapat memberikan kepuasan mereka. Namun sebaliknya, ada beberapa orang yang tidak merasakan kepuasan tersebut hanya sebatas melihat dan mengamati tidak akan memberikan kepuasan untuknya.

"Kalau dapat kepuasan sebenarnya biasa saja sih karena itu kan cuma visual jadi tidak ada kepuasan apa-apa kan cuma oh ini cantik oh ini tidak kalau misalnya kepuasan kan tidak bisa dari visual saja kan ya menurutku harus ada yang apa namanya kontak fisik nah itu baru kepuasan" (Informan 5, wawancara, 2020).

Dari pernyataan informan 5, dapat diketahui bahwa dia menormalkan hal-hal yang berkaitan dengan mengintip hanya dengan alasan bahwa dia laki-laki. Seolah-olah itu adalah hal biasa bagi laki-laki untuk mengintip lawan jenis di media sosial.

"Kalau kepuasan tersendiri sih ya biasa aja sih. Ah tapi mungkin nanti mau tak lihatin ke temen apa buat tak share ke temen gitu lo" (Informan 7, wawancara, 2020). Beberapa pernyataan ini menunjukkan bahwa para pengintip tidak merasa mendapat kepuasan tersendiri setelah melakukan voyeurism atau melihat konten-konten yang berkaitan. Informan 5 mengatakan bahwa hal tersebut hanya visual sehingga tidak akan menimbulkan kepuasan kecuali dengan adanya kontak fisik antara korban dan pelaku voyeurism. Meninjau kembali apa yang diungkapkan oleh informan 7, mereka akan menyimpan konten dan membagikannya kepada teman. Setelah itu, mereka akan membicarakan entah terkait fisik orang tersebut dan apabila merasakan kepuasan mereka akan mengikuti atau mem-follow orang tersebut agar mendapatkan notifikasi setiap orang tersebut mengunggah kontennya.

Berdasarkan wawancara yang telah dilakukan dengan semua informan, dapat diketahui bahwa laki-laki lebih cenderung melakukan voyeurism, dan wanita lebih banyak menjadi korban dari para pelaku voyeurism. Laki-laki tampaknya juga lebih berorientasi seksual dibandingkan dengan perempuan. Para perempuan yang melakukan voyeurism lebih cenderung ke hal-hal lain, terutama demi kebutuhan fashion atau model bagi dirinya.

\section{Voyeurism dan Konteks Medis Sosial}

Kegiatan mengintip memang bukan hal yang sama sekali baru. Namun, keberadaan media memfasilitasi proses tersebut. Penelitian ini juga menunjukkan bahwa praktik-praktik mengintip tidak dapat dilepaskan dari keberadaan media sosial, dan terutama fasilitas yang mereka sediakan. Fasilitas menyediakan sarana bagi pengintip untuk memuaskan hasrat mereka, sedangkan bagi korban (subjek yang diintip) maka media sosial menyediakan sarana untuk memamerkan diri. Pameran inilah yang membuka ruang bagi proses pengintipan tersebut. 


\section{Feeds dan Instastory}

Feeds atau postingan seseorang yang berisi foto atau video, sedangkan instastory yang berisikan video singkat berdurasi 15 detik. Kedua fitur itulah yang dijadikan alat utama oleh pelaku voyeurism. Foto atau video yang ada di feeds dapat disimpan oleh orang lain atau orang tersebut dapat menuliskan komentar yang tidak pantas. Selain itu, instastory atau snapgram juga dapat ditautkan ke nama tempat yang sedang kita kunjungi atau kita juga dapat menuliskan (mention@) nama akun teman yang sedang bersama kita saat itu. Melalui fitur inilah yang dinilai sangat bermanfaat oleh pelaku voyeurism.

"kalau saya tidak sih. Lebih ke temanteman dekat sendiri yang suka meroasting. Misal saya pakai baju yang agak menonjol gitu ya dadanya terus teman saya kadang suka bilang balon atau apa. Kesal tapi teman sendiri dan memang akrab sih, memang kadang tidak tahu tempat saja hehehehe" (Informan 1, wawancara, 2020).

Dari kutipan di atas, dapat diketahui bahwa teman dekat dapat menjadi pelaku voyeurisme, mereka menuliskan komentar yang tidak pantas, bisa jadi mereka merasa hal itu wajar dilakukan karena teman.

"Menurut saya apa yang memicu orang itu sampai mengamati saya ya karena dari SG (snapgram) atau post saya ya tepatnya dari konten. Tapi ya isi konten saya itu ya keseharian dan saya melihatnya mungkin orang itu tu ingin direspon, makanya dia selalu mengomentari SG saya gitu" (Informan 2, wawancara, 2020).

Berdasarkan jawaban informan 2 dimana pelaku voyeurisme mengamatinya melalui SG (instastory) dan selalu mengomentari konten
SG-nya. Informan juga merasa orang yang seperti itu membutuhkan responnya.

"Jujur sampai sekarang pun untuk orang-orang yang mengamati saya itu mengamati dari segi apanya atau dari mananya itu masih kurang paham sih aku, karena kalau saya pribadi masih dibilang pakaian terbuka juga tidak. Mungkin pakaian yang memperlihatkan lekuk tubuh mungkin iya. cuma memang pakaian-pakaian tersebut yang membuat saya nyaman jadi saya tidak pernah merubah pakaian $\mathrm{ku}$ untuk orang lain untuk agar tidak dikomentari yang berbau seksual itu saya tidak akan merubah itu karena kalau menurut saya orang itu dapat melihat dari segi manapun tergantung pikiran mereka saja kemana gitu sih kalo memicu mereka sampai mengirim DM atau komentar saya sendiri tidak tahu dari segi mananya sih memang merekanya saja kalo menurut saya. Maaf yang terakhir itu dari pikiran mereka aja jadi sumbernya itu emang dari pikiran mereka" (Informan 3, wawancara, 2020).

Informan 3 berasumsi bahwa mungkin ketika dia mengunggah konten baik itu di feeds atau snapgram yang menampilkan lekuk tubuhnya, informan juga menerima komentar dan direct message yang tidak pantas. Menurutnya, itu terjadi karena para pelaku tidak dapat mengontrol pikiran dan nafsunya.

Apa yang dapat disimpulkan dari paparan di atas bahwa voyeurism dapat terjadi karena motif atau dorongan dari dalam diri pelaku seperti rasa suka saat mengamati orang lain. Namun, dapat dipicu oleh kondisi atau konteks lain yang mendukung seperti dari konten yang mereka dapat di media sosial Instagram. Hingga saat ini, voyeurism sulit untuk dihilangkan dan sudah menjadi kebiasaan pada hampir sebagian masyarakat (Aprianti, 2014). Beberapa hal yang mendukung bahwa 
voyeurism berkembang menjadi budaya seperti adanya media sosial Instagram dengan berbagai fiturnya mendukung para pelaku melakukan aktivitas voyeurism. Motif yang muncul direalisasikan dengan menggunakan fitur-fitur yang tersedia di Instagram seperti feeds dan instastory, yang mana tempat konten tersebut berasal. Selanjutnya mereka menggunakan fitur send to, save, direct message, like, dan comment.

Penelitian ini berbanding lurus dengan penelitian yang ada sebelumnya dengan judul "Electronic Voyeurism In Global Perspective" yang disusun oleh Chandra (2019). Penelitian ini menjelaskan mengenai rasa ingin tahu yang dimiliki seorang manusia adalah sifat alami dan termasuk dari bagian kehidupan. Dari situlah, para individu berusaha untuk memasuki kehidupan bahkan dengan sikap agresif seseorang dengan cara mengintip melalui media sosial, karena mereka merasa hal itu aman untuk dilakukan. Dalam menggunakan media sosial, tentunya didasari beberapa tujuan dan keinginan untuk mencapai sesuatu seperti aspek berikut, mencari informasi (information seeking) tentang sesuatu merupakan alasan selanjutnya saat seseorang menggunakan media atau Instagram. Informasi tersebut dapat sebagai keperluan pribadi atau untuk dibagikan.

Media juga dapat sebagai hiburan (entertainment) karena dinilai dapat menyajikan konten-konten yang dapat membuat seseorang merasa terhibur, motif selanjutnya adalah bahwa media dapat memberikan kenyamanan (convenience utility) tersendiri bagi para penggunanya Innova (2016). Ketiga motif di atas dapat dijadikan motif utama pelaku voyeurism di media sosial. Pelaku mencari informasi tentang targetnya melalui media, mereka juga menggunakan konten korbannya sebagai hiburan, selanjutnya mereka mendapatkan kepuasan dan kenyamanan dengan beberapa fiturnya.

Motif pelaku yang berasal dari dalam dirinya atau sifat alami bahwa mereka hanya suka mengamati orang lain khususnya lawan jenis. Sedangkan konteks atau kondisi yang mendukung adalah konten-konten yang tersedia di media sosial Instagram khususnya feeds dan instastory, karena dari feeds dan instastory para pelaku dapat mengetahui apa yang dilakukan targetnya atau apapun yang berkaitan dengan targetnya. Dari hasil wawancara, cara yang sering target lakukan untuk menyudahi hal ini adalah dengan melakukan pemblokiran akun. Tidak berhenti sampai disitu, pelaku tetap dapat mengamati targetnya dengan membuat akun baru yang sering disebut fake account. Penelitian ini juga meneguhkan kajian Rye \& Meaney (2007) bahwa pelaku voyeurism sebagian besar adalah pria serta sebagian besar wanita adalah korban dari adanya voyeurism termediasi.

\section{SIMPULAN}

Berdasarkan data lapangan, penelitian ini menunjukkan bahwa semua informan yang berasal dari kalangan mahasiswa di Kota Yogyakarta pernah melakukan dan menerima tindak voyeurism dengan menggunakan fitur comment, like, saved, send to, direct message, instastory, dan juga post. Para pelaku mengaku bahwa rasa suka mengamati orang lain tersebut wajar dan merupakan sifat alami. Siapapun dapat menggunakan fitur tersebut dan akan ditujukan kepada siapapun.

Berdasarkan hasil penelitian, para pelaku voyeurism sering melakukan spamming pada fitur direct message. Hal yang sama seperti yang dialami oleh korban adalah sering menerima pesan singkat dari orang yang tidak dikenal ataupun dikenal melalui direct message dengan bahasa yang kurang pantas. Pelaku juga menyimpan dan membagikan konten. Selanjutnya, mereka akan membicarakan orang yang ada dalam konten tersebut (membicarakan bagian tubuh yang dirasa menarik dari korban), dan hal itu memenuhi hasrat seksual mereka.

Para pelaku tidak memandang korbannya baik itu teman atau followers yang mereka kenal atau tidak mereka kenal sama sekali. Namun, mereka memiliki beberapa kriteria tertentu untuk orang yang akan mereka diamati seperti wanita dengan penampilan 
menarik. Menarik dalam artian berwajah cantik, badan yang proporsional menurut mereka, maka akan menjadi sasaran mereka. Untuk mencari korbannya, mereka lebih banyak menggunakan fitur post (feeds) dan instastory.

Motif pelaku selain rasa suka mengamati orang lain yang muncul dari dalam dirinya, juga ditentukan oleh keberadaan media sosial. Utamanya, fasilitas yang disediakan media sosial tersebut. Melalui feeds dan instastory. pelaku memperoleh beberapa bahkan hampir seluruh informasi mengenai targetnya. Terlebih feeds Instagram yang berisikan foto maupun video dapat disimpan secara cuma-cuma oleh orang lain.
Saran yang dapat diberikan peneliti mengenai penelitian voyeurism di kalangan mahasiswa di Yogyakarta bahwa mengunggah momen pada media sosial Instagram adalah hal yang dapat dilakukan oleh siapapun dan kapanpun. Namun, hal itu harus dilakukan secara hati-hati ketika mengunggah dirinya karena hal itu akan memancing voyeurism. Oleh karena itu, sebaiknya, para pemilik akun media sosial Instagram mengerti akan batasan. Hal itu juga dapat mencegah terjadinya penyalahgunaan informasi oleh orang lain. Penelitian lebih lanjut mungkin dapat dilakukan kepada korban terutama yang berhubungan dengan pengalaman mereka menjadi korban kegiatan voyeurism. 


\section{DAFTAR PUSTAKA}

Aprianti, R. (2014). Budaya media dan lahirnya spectacle society. Jurnal Wardah, 15(2).

http://jurnal.radenfatah.ac.id/index. php/warda/article/view/199

Calvert, C. (2009). Media, privacy, and peering in modern culture. In Voyeur Nation.

https://books.google.co.id/books/ab out/Voyeur_Nation.html?id=GxFiAA AAMAAJ\&redir_esc $=\mathrm{y}$

Chandra, R. (2019). Electronic voyeurism in global perspective. International Journal Of Legal Developments and Allied Issues, 5(5).

https://thelawbrigade.com/criminallaw/electronic-voyeurism-in-globalperspective/

Green, S. P. (2017). To See and Be Seen: Reconstructing the Law of Voyeurism and Exhibitionism. American

Criminal Law Review, 54 . https://papers.ssrn.com/sol3/papers .cfm?abstract_id=2983894

Innova, I. E. (2016). Motif dan kepuasan pengguna instagram di komunitas instameet Indonesia. Jurnal EKomunikasi, 4(1).

http://publication.petra.ac.id/index. php/ilmu-

komunikasi/article/view/4851/446o

Moleong, L. J. (2011). Metodologi

Penelitian Kualitatif Edisi Revisi. In PT. Remaja Rosdakarya.

Nasrullah, R. (2016). Media Sosial Perspektif Komunikasi, Budaya, Sosioteknologi. In Simbiosa Rekatama Media (Cet.kedua).
Ningtyas, A. H. (2016). Mediated voyuerism dan media sosial studi deskriptif kualitatif praktik mediated voyeurism pada media sosial path mahasiswa ilmu komunikasi Fisip UNS Surakarta angkatan 201O-2012 [UNS Surakarta]. Mediated Voyeurism dan Media Sosial (Studi Deskriptif pada Media Sosial Path Mahasiswa Ilmu Komunikasi FISIP UNS Surakarta Angkatan 2010-2012

Rye, B. J., \& Meaney, G. J. (2007). Voyeurism. International Journal of Sexual Health, 19(1), 47-56. https://doi.org/10.1300/J514v19no1 _o6

$\mathrm{Su}, \mathrm{P} . \mathrm{J}$. (2012). Mediated voyeurism on social network sites: The possible social needs and potential motivations of the voyeur on facebook. Rochester Institute of Technology ScholarWorks.

Sugiyono. (2009). Statistika untuk penelitian. CV. Alfabeta.

Yalom, I. D. (1960). Aggression and forbiddenness in voyeurism. Archives of General Psychiatry, 3(3), 305. https://doi.org/10.1001/archpsyc.19 60.01710030091012 
Nadia Sofiyant \& Puji Rianto 